\title{
The Impact of Foreign Portfolio Investment and Corporate Governance on Corporate Cash Holdings: Evidence from the Leading Manufacturing Sectors in Pakistan
}

\author{
Hina Gul, Sajida Gul and Shahid Rasheed
}

\begin{abstract}
- corporate governance plays a significant role in determining cash holdings of the corporation. The behavior of corporate manager in companies where the protection of rights of the shareholders is week leads to the problem of agency. The key aim of this study is to scrutinize the influence of foreign portfolio investment and corporate governance on corporate cash holdings. For analysis trade off theory, agency cost theory and Modern Theory of Portfolio are reviewed. The study is performed by taking 67 listed manufacturing firms in the Pakistan stock exchange for the period of 2013-2018. Chow test, Breusch-Pagan Lagrange Multiplier (LM) Test and Housman specification test performed for data analysis. The results showed that FPI inflow has a significant and negative impact on cash holdings. In terms of corporate governance ownership concentration has a significant and negative impact on the cash holdings while board size significant and positive impact and board independence has an insignificant and positive impact on the cash holdings. This study concluded that corporate governance practices must be improved and made effective in such a way so as to attract and retain investment and also protect the shareholders rights and managers must perform in the best concern of the shareholders by investing cash in healthy projects to minimize the agency conflict.
\end{abstract}

Index Terms - Corporate cash holdings, Foreign Portfolio Inflow (FPI), Corporate Governance, Ownership concentration, Board size, Board independence.

\section{INTRODUCTION}

For a company the liquid assets like cash can act as a double-edged weapon. Because these liquid assets can provide flexibility to the firms so as to keep away from the costs of failure to invest in projects having positive net present value due to deficiency in resources on one hand. While alternatively, managers or directors benefits are subject to cash investment in projects having negative net present value [20], [48]. It is the desire of any business to grasp sufficient sum of cash but the questions arise here are 1) why a large sum of cash holding by a firm? 2) What are the determinants which influence the decisions of cash holdings taken by the managers? A cash holding is defined in the Finance Literature as "A sum of cash and cash

Published on July 28, 2020.

Hina Gul, Abasyn University Peshawar, Pakistan.

(corresponding e-mail: hina.gul@abasyn.edu.pk)

Sajida Gul, Abasyn University Peshawar, Pakistan.

(e-mail: sajida.gul@abasyn.edu.pk).

Shahid Rasheed, Abasyn University Peshawar, Pakistan.

(e-mail: shahid.rashid@abasyn.edu.pk). equivalents" [40], [14], [41], [6].

The most liquid asset is cash which plays a significant role in corporate finance. One of the most important issues for the corporation is corporate cash holding and in order to solve this issue corporate financial management will make strategies which affect not only the corporate operation and development, but also have an impact on the governance of the corporation and the environment of the institution. For proper operation of the company an adequate liquidity level is maintained within the company the cash level is characterized by structure of capital, working capital, management of the cash flow, payment of dividends, investment and asset management policies [40].

The Economic theories that hold the decisions of the firm's cash holdings are the theory of trade off, the theory of pecking order and the theory of cost of agency. According to the theory of tradeoff, companies weighting the marginal cost and benefits of holdings cash in order to establish the optimal cash level. The marginal cost of holding cash is mainly the cost of opportunity connected with cash that is holding back the current temporary investments that are earlier for motives of transactional or precautionary [40].

Jensen and Meckling [21] lead to principal-agent theory, proposed that corporate liquidity may cause problems of agency between managers and shareholders as cash can supply finances for managers to invest in projects that destroy shareholder value. When the agency theory comes to corporate cash holdings they hold two hypotheses: hypothesis of cash flow and hypothesis of risk reduction. Similarly, Modern Theory of Portfolio, describes that optimal portfolios can be created by considering the relationship between return and risk. A hypothesis put forth by Harry Markowitz is a theory of investment based on the proposition that risk-averse shareholders can make portfolios to maximize or optimize expected return on the basis of a certain rank of market risk, highlight that risk is an intrinsic element of the highest reward [33].

Corporate cash holdings affected by various factors, but this study focused on two factors, that is, foreign portfolio investment (FPI) and corporate governance because no one checked the combined impact of foreign portfolio investment and corporate governance on corporate cash holdings. Chaudhry Fatima and Arzoo [10] stated that in order for the firms to internationalize the internationalization of market encouraged the firms to formulate varied approaches, which resulted in broad actions for instance foreign investment. Investment is the reliability of capital 
(money) to acquire monetary instruments and additional financial assets so as to obtain profitable returns in the shape of interest in addition to the positive response of the value of the instrument. The majority of the studies highlighted on the optimistic side of foreign resources on the growth of the economy. Foreign capitals recover the procedure of development of the economy by filling the space between investment and savings. The flows of foreign capital are into two classes: foreign private investment and foreign aid. The most vital basis of foreign capital is foreign private investment. Foreign private investment is further categorized into Foreign Portfolio Investment (FPI) and Foreign Direct Investment (FDI)

Foreign portfolio investment is also known as "hot money". Portfolio investment is a bunch of financial investment securities and other financial assets detained by foreign shareholders. These financial securities are easily traded and are less everlasting [31]. Foreign portfolio investment frequently engages short-range position in the financial assets of worldwide markets, and is likely to invest in domestic securities. Foreign Portfolio Investment permits shareholders to play a role in the profitability of companies working overseas without having to directly administer their operations. This concept is likely to trading domestically. It includes bonds, stocks, dividends, debt securities, and mutual funds of different companies from overseas and domestic [10].

Cash holdings can serve as laudable purposes; it allows the corporation to make profitable investment opportunities as they occur [23] or on the other hand they may indicate agency problems. So as to decrease the problems of agency a system of corporate governance is used. Corporate governance is defined by the La Porta, Lopez-de-Silanes, Shleifer \& Vishny. [30] as "A set of mechanism through which outside investors protect themselves against the expropriation by the insiders". They defined "insiders" as both managers and controlling shareholders. In order to control the agency problems corporate governance serves as a documentation purposes. The motive for particular attention to managerial ownership lies with the problems of agency that may be varied for shareholders, minority shareholders, and bondholders. In accordance with the literature of agency, managers get greater discretion when the level of holdings cash is high. Papaioannou et al [43] put forward that managers hold additional cash as resistance, and Myers and Rajan [38] suggested that from the liquid assets managers can get more personal benefits. Opler et al. [40] also suggested that instead of paying cash as a dividend to the shareholders entrenched managers choose to hold cash. As a result, shareholders wish to bind the cash discretion of managers [20], [48]. As the main determinant of corporate liquidity the mechanism of corporate governance provides the stakeholders with the opportunity to tie effective the discretion of managers. Good governance maximizing the wealth of the stakeholders and a realistic cash quantity, although the consequences of weak governance are a major conflict of interest [17].

As most of the work has been done in which the impact of corporate governance on cash holdings has been analyzed at both the national and international level. The impact of foreign portfolio investment on cash holdings has not been analyzed till yet, nor the impact of corporate governance and foreign portfolio investment been analyzed. The current study investigates the impact of foreign portfolio investment and corporate governance on corporate cash holdings in the leading manufacturing sectors in Pakistan for the period of 2013-2018. The variables such as Ownership structure and board structure are taken as corporate governance. And on the other hand the variable of foreign portfolio investment is taken as foreign portfolio inflow. While Firm size, Cash flow volatility, Growth Opportunity, Capital expenditures, Dividend payout, Leverage has been taken as the control variables.

\section{Problem Statement}

Cash is the important factor of a firm's assets because this cash holding keeps the firms in the liquid position. In order to ensure the future operations, to pay all the obligations, and to attract the good investment opportunities firms have an incentive to keep cash. Opler et al. [40] proposed that companies have a tendency to keep more money as they have excellent opportunities for investment and high cash flow risks. However, large quantity of cash holding might result in the troubles of agency of free cash flow and to minimize the problems of agency a system of corporate governance is used.

Foreign portfolio investment has the desirable quality of stimulating the growth of the home stock market. The catalyst for this growth is rivalry from foreign financial institutions. This rivalry necessitate the importation of more complicated financial tools, version of the technology to home environment and superior investment in financial services and information processing. The outcomes are better efficiencies in distributing capital, risk sharing and examining the issue of capital. This change of effectiveness due to internationalization makes the market more liquid, which coordinates to a lesser cost of capital. The foreign capital cost additionally has a tendency to be lesser, in light of the fact that the foreign portfolio can be more extended over the national limits and subsequently be more equipped in diminishing nation particular risks, bringing about a lesser risk premium. An extremely sensitive stock market has also its impact on the side of demand. It gives investors with assets selection with variable level of risk, return and liquidity. This prolonged choice of benefits and the survival of an enthusiastic securities exchange give investors with greater liquidity and alternatives, along these lines activating more funds [42].

Studies undertaken on the impact of corporate governance on cash holdings include: Khan, Bibi and Tanveer [24] determined the impact of corporate governance on cash holdings: a comparative study of the manufacturing and service industry; Wai \& Zhun [49] analyzed the effect of corporate governance on cash holdings by using 160 firmyear observations from 2010 to 2011 from Hong Kong listed companies; Kusnadi and Wei [28] analyzed the corporate governance mechanisms on firm level and its relationships to cash holding, and how they affect firm value; Masood and Shah [35] studied the impact of corporate governance on corporate cash holdings variables in the framework of Pakistan by taking a sample of 309 non-financial firms listed 
on the Pakistan Stock Exchange (PSE) for the period of 2002-2010; Basheer [7] analyzed the effect of corporate governance on decisions of managerial of cash holding on the basis of agency theory. In terms of foreign investment, most of the research work has been conducted in which the impact of foreign investment to economic growth, capital formation, technology transfer, promotion of imports and exports and the networking effect of marketing etc. in different sectors of the economy have been analyzed. The impact of foreign direct investment and corporate governance on corporate cash holdings was analyzed by only Kiyoung and Abbas [25] by taking data for about 22,000 companies from 48 countries.

The direct impact of foreign portfolio investment on cash holdings was not analyzed till yet. Neither, none of the study has been done in which the impact of foreign portfolio investment and corporate governance has been analyzed this area of research has not been covered till yet that's why the current study focus on analyzing the impact in the leading manufacturing sectors in Pakistan from the period of 20132018 so the following questions consider that what is the impact of foreign portfolio investment and corporate governance affect corporate cash holding

\section{A. Research question}

Does foreign portfolio investment and corporate governance affect corporate cash holdings?

\section{B. Research objective}

To analyze the impact of foreign portfolio investment and corporate governances on corporate cash holdings.

\section{LITERATURE REVIEW}

The most liquid asset is cash that allows the company to pay its obligations in time. Cash holdings provide companies with liquidity, therefore, is important; i.e., companies are capable to pay its debts on time, though bad times come. So as to maximize sales and profits, a company needs to put up reserves of cash to ensure that overall situation of positive cash flow is created by the timing of cash flows. Therefore, the necessary factor is the cash that allows a company to endure and flourish [11]. Cash holdings in the framework of this study, is defined as "cash in hand or readily available for investment in physical assets and to distribute to the investors". Firms have a certain amount of liquid equilibrium, in the spirit postulates of the Keynesian demand for money, to a variety of reasons, as a precaution, speculative, and transactional [2].

Foreign Portfolio Investment (FPI) consists of securities and other financial assets inertly detained by foreign shareholders. Portfolio Investment by nature is extremely liquid and easy to exchange into cash in any time. Because of the high volatility of Foreign Portfolio Investment the Asian Economic Crisis of 1997 took place. At the moment of financial disaster huge quantity of assets have rehabilitated into cash. At any time from the portfolios shareholders can sale their financial instruments, depends on shareholder's choice. In Pakistan portfolio investment will direct to a structure of capital of organizations by improving the incentives of managers and value of firms [10].
According to the Organization for Economic Cooperation and Development (OECD). (1999), corporate governance is defined as "the system by which business corporations are directed and controlled". The corporate governance is defined by Raithatha and Bapat [45] as "the general control of the activities of a corporation" an information taken from the global database Scope 2000 at the 2000 end, the median firms between 20,987 major companies in 48 countries of the world held $8.90 \%$ of its net assets as cash and other highly liquid. The following variables used for corporate governance are mentioned below:

\section{A. Ownership structure}

Literature showed that the internal corporate governance mechanism is based on ownership structure [44]. Keeping in view a firm's authority, profit generation and performance, ownership structure is considered as an important factor [4]. By considering its significance in corporate governance, researchers have used different dimensions of ownership structure as per their topic under investigation such as Masood and Shah [35] mentioned three dimensions namely director's ownership, institutional ownership and ownership concentration. While in another study by Almudehki and Zeitun [2] four different dimensions of ownership concentration are observed namely board ownership, concentrated ownership, foreign ownership, and institutional ownership.

\section{B. Ownership Concentration}

Jensen and Meckling [21] suggested that due to the division of ownership and control, managers have power over the company resources that can directly expropriate wealth from other stakeholders.

\section{Board Structure}

Board structure plays an important role in determining corporate cash holdings to measure the impact of board structure on cash holdings this study considered two variables board size and board independence

\section{Board Size}

A company board of directors is liable for evaluating and monitoring higher management. Yermack (1996) found that smaller boards are more competent since they provide better decision making. Many studies suggested that company's performance is better when the board size is smaller [13], [32], [3]. The reason is that decision making process is more effective in a small board [50], [32]. [15] and [27]. indicated that larger board Size Company has more cash holdings. In contrast, [34], [29] and [12] documented that board size has no significant effect on corporate performance.

\section{E. Board Independence}

Ozkan and Ozkan [41] proposed that outside board monitoring can provide superior protection of Shareholder. Opler et al. [40] found a linear relationship between board independence and cash holdings.

Control variables

The following control variables are discussed below

i. Firm size

Under the assumption that large companies are better diversified than smaller companies, Bates, Kahle and Stulz 
[6] state that large size of companies are more likely to be reliable to settle part of non-strategic assets to raise cash, which is reduced the possibility of encountering financial difficulties. Barclay and Smith [5] state that there are economies of scale resulting of the large fixed cost of public issuance. Make large companies appear to reduce the cost of raising money in the capital market that small businesses owe because of these economies of scale. Therefore, small businesses tend to have more cash to avoid these costs. In short, firm size is related negative to cash holdings. In accordance with the Theory of Trade off negative relation exist between cash flow and firm size. Ozkan \& Ozkan [41] and Opler et al [40] found a positive relation between cash holding and size of firm.

\section{ii. Cash flow volatility}

Volatility in cash flows is another determinant of cash holding that arises when future expected payments are not regularly received and cost of financial distress goes up. Therefore, by following Trade off theory such firms hold more cash and a positive relation is expected between cash flow volatility and cash holdings [19], [40], [41] and [14].

\section{iii. Growth Opportunity}

Firms having more growth opportunities may want to raise capital either through debt or by issuing securities. If a firm is highly leveraged then cost of issuing new bonds and shares will be high [19]. Therefore, following pecking order theory, the cost of cash holding would be less expensive in such a case. Firms that have better access to capital markets and more substitutes available for cash tend to hold less cash [9]. Ozkan \& Ozkan [41], Megginson \&Wei [36] all found a positive relation between firm's cash holdings and growth opportunities.

iv. Capital expenditures

According to Bates, Kahle and Stulz [6], if the assets created by capital expenditures could be used as collateral, then the capital expenditure is inversely connected to cash holdings, since that could reduce the demand for cash and improve borrowing capacity

v. Dividend payout

Bates, Kahle and Stulz [6] states that the payment of dividends is a positive sign of the companies to the public, therefore, companies that pay dividends usually have higher admittance to markets of capital. As a result, they tend to have less cash. Ozkan \& Ozkan [40] and Ferreira and Vilela [14] found a negative association between payments of dividend and cash holdings.

vi. Leverage

When the shortage of cash occurs, companies could borrow debts as a solution. As a result, debt is considered as a replacement for cash. Leverage ratio is an indicator of the company "s ability to take on debt. Baskin (1987) states that the cost of investment in liquid assets increases with the leverage ratio, it is representing that the cash holdings are declining debt in the capital structure. Therefore, in the view the transaction motive, leverage is negatively related to cash holdings. Ozkan \& Ozkan [40] and Opler et al. [41] also found negative relationship between cash holdings and leverage.

\section{F. Corporate Cash Holdings and Corporate Governance around the World}

Previous researches on the connection between corporate cash holdings and corporate governance had debatable outcomes. Wai and Zhun [49] analyzed the corporate governance impact on cash holdings by taking a sample of 160 firms from the period of 2010-2011 from listed companies of Hong Kong. The relationship between governance of corporation and the holdings of cash depend on size of the corporation. They found that there is a negative relationship between the duality of CEO (CEO is also the chairman) and cash holdings, and a positive relationship between the CEO ownership and cash holdings.

Kengatharan [26] by taking 26 manufacturing companies listed on the Colombo Stock Exchange from the period of 2011-2015. The findings showed that CEO-duality and leverage has significant negative impact whereas firm size and audit committee meetings firm size had positive impact while Board independence, board size and audit committee members has an insignificant impact on cash holdings

\section{G. Corporate Cash Holdings and Corporate Governance in the Context of Pakistan}

Masood and Shah [35]) studied the impact of corporate governance on corporate cash holdings by taking a sample of about 309 non-financial firms listed on the Karachi Stock Exchange (KSE) for the period of 2002-2010. The findings showed a linear connection between corporate cash holdings and managerial ownership. While Basheer [7] found a nonlinear connection between corporate cash holdings and managerial ownership by taking 138 non-financial listed firms on the KSE from the period of 2008-2012.

\section{H. Corporate Cash Holdings and Foreign Portfolio Investment}

The direct impact of FPI on cash holdings has not been analyzed till yet but most of the work has been done by in which the impact of FPI on economic growth, factors affecting FPI, financial constraints of small firms and macro-economic factors were analyzed.

\section{Theoretical Model}

On the basis of literature review the following theoretical model was formulated.

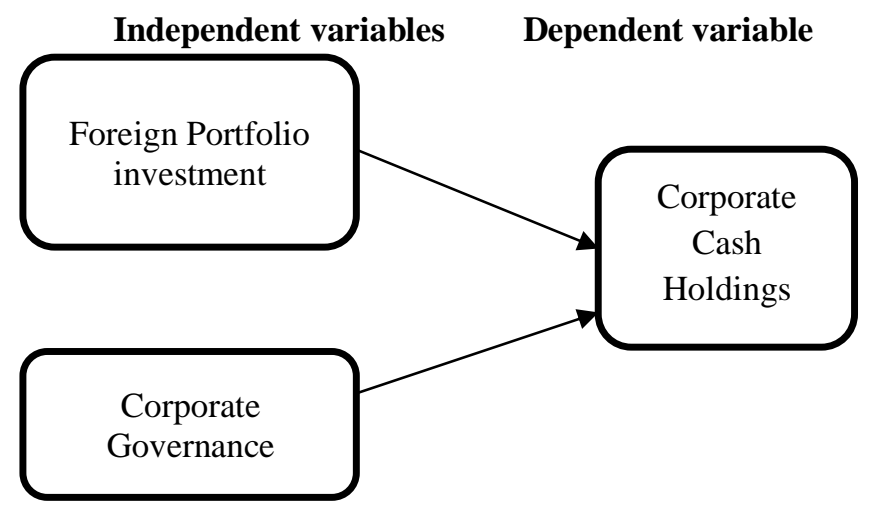

Fig. 1. Present the theoretical model of the study 


\section{Research Hypotheses}

$\mathbf{H}_{1}$ : There is a significant impact of the foreign portfolio investment on the corporate cash holdings.

$\mathbf{H}_{2}$ : There is a significant impact of the corporate governance on the corporate cash holdings

\section{Research Methodology}

By reviewing past literatures the current study based on descriptive and quantitative in nature by applying statistical tools and ratio analysis. Secondary data techniques have been used for this research. The data has taken from the company annual report from the State Bank of Pakistan and Pakistan Stock Exchange (PSX). In the period of 2013 to 2018 there were total 638 firms (non-manufacturing and manufacturing) listed on the Pakistan Stock Exchange (PSE) and these firms were categorized in to 33 sectors or stratum, a sample of 11 sectors (manufacturing) selected via simple random sampling, which contained 317 listed firms from which 67 firms are selected by proportional allocation method. The selected sectors such as; Automobile, assembler Parts and electrical goods contain 30, Chemicals contain 34, cement sector contain 22, Engineering contain 18 , Electricity (power) sector contain 15, Pharmaceuticals contain 9, glass and ceramics contain 8, Food producer (personal care products and sugar) contain 54, Industrial metals and Mining contain 10, oil and gas sector contain 18 and Personal goods sector contain 99 listed companies. Proportional allocation method uses the following formula for selecting the no of units from each of the stratum.

$$
n 1=n / N \times N 1
$$

where,

$\mathrm{n}=$ size of the required sample;

$\mathrm{N}=$ size of the population;

$\mathrm{N} 1=$ Size if $\mathrm{i}^{\text {th }}$ strata;

$n 1=$ size of sample to be taken from $\mathrm{i}^{\text {th }}$ strata.

\begin{tabular}{|c|c|c|}
\hline & Names of Variables & Measured By \\
\hline \multicolumn{3}{|l|}{ Dependent Variable } \\
\hline & Cash holding & $\begin{array}{l}\text { The ratio of cash and cash equivalent to net assets while net assets are, } \\
\text { total assets minus cash and cash equivalent [41] }\end{array}$ \\
\hline \multicolumn{3}{|l|}{ Independent Variables } \\
\hline & Foreign Portfolio Investment & $\begin{array}{l}\text { The log of foreign Portfolio inflow. Whereas, foreign Portfolio inflow is } \\
\text { the number of shares held by foreign shareholders }\end{array}$ \\
\hline Ownership structure & Ownership Concentration & $\begin{array}{l}\text { Top five insiders' holdings of the common shares to total no of } \\
\text { outstanding shares [17] }\end{array}$ \\
\hline \multirow[t]{2}{*}{ Board Structure } & i. Board Size & Overall number of directors serving on the board Harford et al; (2008). \\
\hline & ii. Board Independence & The ratio of independent directors to total directors. [17] \\
\hline \multicolumn{3}{|l|}{ Control variables } \\
\hline & i. Firm size & A natural $\log$ of sales [41] \\
\hline & ii. Cash flow volatility & $\begin{array}{l}\text { The standard deviation taken of cash flow to the average taken of total } \\
\text { assets. Whereas, cash flow is calculated as pretax income plus } \\
\text { depreciation divided by net assets [14]. }\end{array}$ \\
\hline & iii. Growth Opportunity & Market to book ratio $[41]$ \\
\hline & iv. Capital expenditures & The capital expenditure to total net assets [41]. \\
\hline & v. Dividend payout & $\begin{array}{l}\text { The proxy used for dividend is the dividend dummy for policy of } \\
\text { dividend, specifically, dummy equals } 1 \text { if the firm pay dividend in a } \\
\text { specified period other wise } 0 \text { [16]. }\end{array}$ \\
\hline & vi. Leverage & Total debt to total assets [40]. \\
\hline
\end{tabular}

\section{A. Analytical Model}

So as to accomplish objective of the study the following model will be used:

$\mathrm{CH}_{\mathrm{i}, \mathrm{t}}=\beta_{\mathrm{o}}+\beta_{1} \mathrm{FPI}_{\mathrm{i}, \mathrm{t}}+\beta_{2}$ owner $_{\mathrm{i}, \mathrm{t}}+\beta_{3}$ bsize $_{\mathrm{i}, \mathrm{t}}+\beta_{4}$ bind $_{\mathrm{i}, \mathrm{t}}+\beta_{5}$ Size $_{\mathrm{i}, \mathrm{t}}+\beta_{6} \mathrm{Lev}_{\mathrm{i}, \mathrm{t}}+\beta_{7} \mathrm{CF}_{\mathrm{i}, \mathrm{t}}+\beta_{8} \mathrm{Gth}_{\mathrm{i}, \mathrm{t}}+\beta_{9} \operatorname{Div}_{\mathrm{i}, \mathrm{t}}+\beta_{10}$ Capex $_{\mathrm{i}, \mathrm{t}}$

$$
+\epsilon_{\mathrm{i}, \mathrm{t}}
$$

\section{Results And Discussion}

\section{A. Data Description and Tests}

For the analysis of 67 manufacturing companies for 6 years (2013-2018) different types of tests were performed they were collinearity test for multicollinearity, BreuschPagan test for heteroskedasticity, descriptive statistics and panel data analysis for the suitable regression model selection.

\section{B. Multicollinearity}

Multicollinearity examined and found that the variance inflation factor of all the explanatory variables is lower than 10 which shows that the explanatory variables are not correlated and faces no problem of multicollinearity (see table 2).

TABLE 2: TEST RESULTS OF MULTICOLLINEARITY

\begin{tabular}{|l|l|}
\hline Variables & VIF \\
\hline FDI & 1.30 \\
\hline Ownco & 1.19 \\
\hline Bsize & 1.33 \\
\hline Bind & 1.19 \\
\hline Firm size & 1.07 \\
\hline Leverage & 1.23 \\
\hline Cfvola & 1.14 \\
\hline Gorwthopp & 1.14 \\
\hline Dividend & 1.17 \\
\hline Capexp & 1.06 \\
\hline Mean VIF & 1.18 \\
\hline
\end{tabular}




\section{Breusch-pagan test for heteroskedasticity}

Heteroskedasticity detected by Breusch-Pagan test which shows the presence of heteroskedasticity. This problem is adjusted by using robust standard error (see table 3 ).

TABLE 3: RESULTS OF BREUSCH-PAGAN FOR HETEROSKEDASTICITY

\begin{tabular}{|c|c|c|c|}
\hline Hypothesis & $\begin{array}{c}\text { Chi- } \\
\text { square }\end{array}$ & $\begin{array}{c}\text { P- } \\
\text { value }\end{array}$ & Decision \\
\hline $\begin{array}{c}\text { Ho:variance are } \\
\text { homoskedastic } \\
\text { Hi: variances are } \\
\text { Heteroskedastic }\end{array}$ & 12.99 & 0.0003 & $\begin{array}{c}\text { Variances are } \\
\text { Heteroskedasticity }\end{array}$ \\
\hline
\end{tabular}

\section{Descriptive statistics}

The Descriptive Statistics table showed that there is a realistic differentiation between the maximum and minimum values of all the variables. Amongst all the variables size of the board has the biggest mean value of 8.08. In addition, the table demonstrates that the mean values of all variables excluding growth opportunity are closer to their standard deviation and there exist no problem of data variability with these variables. Alternatively, growth opportunity has the highest standard deviation values of 3.91 it means that there exists volatility in this variable and they faces data variability problem (see Table 4).

TABLE 4: DESCRIPTIVE STATISTICS

\begin{tabular}{lcccc}
\multicolumn{1}{c}{ Variables } & Mean & Minimum & Maximum & Std.Dev \\
\hline Cash Holdings & 0.04 & 1.872 & 2.09 & 0.28 \\
$\begin{array}{l}\text { ForeignDirect } \\
\text { Inflow }\end{array}$ & 7.91 & 3.00 & 15 & 2.03 \\
$\begin{array}{l}\text { Ownership } \\
\text { oncentration }\end{array}$ & 2.97 & 0.0001 & 13.7 & 3.01 \\
$\begin{array}{l}\text { Board Size } \\
\text { Board }\end{array}$ & 8.08 & 4 & 15 & 1.73 \\
$\begin{array}{l}\text { Independence } \\
\text { Firm Size }\end{array}$ & 0.52 & 0.067 & 1 & 0.28 \\
$\begin{array}{l}\text { Leverage } \\
\text { Cash }\end{array}$ & 7.15 & 4 & 10 & 1.31 \\
$\begin{array}{l}\text { Volatility } \\
\text { Growth } \\
\text { Opportunity }\end{array}$ & 0.58 & .006 & 1.87 & 0.29 \\
$\begin{array}{l}\text { Dividend } \\
\text { Capital } \\
\text { Expenditure }\end{array}$ & 0.47 & 0.0004 & 6.8 & 0.79 \\
\hline
\end{tabular}

\section{E. Tests used for the identification of panel data analysis}

Chow test was performed to choose fixed effect model is suitable or pooled OLS model is suitable. The BreuschPagan Test was performed to make a decision either pooled OLS model is suitable or random effect model is suitable. Hausman Specification test was performed so as to select the most reliable and efficient model between fixed effect model and random effect model. (See table5):

TABLE 5: MODEL IDENTIFICATION TEST FOR PANEL DATA

\begin{tabular}{|c|c|c|c|c|}
\hline Test & Hypothesis & Test statistic & P-value & Decision \\
\hline $\begin{array}{c}\text { Chow } \\
\text { Test }\end{array}$ & $\begin{array}{c}\mathrm{H}_{\mathrm{O}} \text { : Pooled OLS is } \\
\text { suitable } \\
\mathrm{H}_{\mathrm{I}} \text { : Fixed effect is } \\
\text { suitable }\end{array}$ & $\mathrm{F}=3.85$ & 0.000 & $\begin{array}{c}\text { Fixed effect } \\
\text { is suitable }\end{array}$ \\
\hline $\begin{array}{c}\text { Breusch- } \\
\text { Pagan } \\
\text { LM test }\end{array}$ & $\begin{array}{c}\mathrm{H}_{\mathrm{O}} \text { : Pooled OLS is } \\
\text { suitable } \\
\mathrm{H}_{\mathrm{I}}: \text { Random effect } \\
\text { is suitable }\end{array}$ & $\mathrm{Chi}^{2}=179.97$ & 0.0000 & $\begin{array}{c}\text { Random } \\
\text { effect is } \\
\text { suitable }\end{array}$ \\
\hline $\begin{array}{c}\text { Hausman } \\
\text { test } \\
\text { effect } \text { is sundom } \\
\mathrm{H}_{\mathrm{I}}: \text { Fixed effect is } \\
\text { suitable }\end{array}$ & $\mathrm{Chi}^{2}=353.58$ & 0.0009 & $\begin{array}{c}\text { Fixed effect } \\
\text { is reliable } \\
\text { and efficient }\end{array}$ \\
\hline
\end{tabular}

DOI: http://dx.doi.org/10.24018/ejbmr.2020.5.4.225

\section{F. Impact of fpi and corporate governance on corporate cash holdings}

The impact of FPI inflows and corporate governance on corporate cash holdings is analyzed. The findings showed that a significant and negative relationship exist between corporate cash holdings and FPI. The regression coefficient value is negative, i.e. -0.042 with a $\mathrm{P}$ value of 0.038 $(\mathrm{P}<0.05)$ which is significant to the $5 \%$ level of significance. The existence of negative relationship between corporate cash holdings and FPI specifies that corporate cash holding decreases with the increase in FPI and if FPI is increased by 1 unit corporate cash holding decreases by 0.001 units means that the firms tends to hold less cash holdings as the FPI inflow increases, hence, the corporate manager seemed the FPI inflows as a substitute for cash. The findings showed that a significant and negative relationship exist between corporate cash holdings and concentration of ownership. The value of regression coefficient for ownership concentration is -0.023 with a $\mathrm{P}$-value of $0.027(\mathrm{P}<0.05)$ which is significant to the $5 \%$ significance level. The inverse relationship support the agency theory and also hold up the hypothesis on the basis of literature emphasizes that within an effective corporate governance mechanism, i.e., agency problems can be minimized when shareholder rights are in good protection and managers can act in the benefit of investors. The results are reliable with the findings of Ozkan and Ozkan [40].

The results specified that a significant connection exist between size of the board and corporate cash holdings. The coefficient value of regression is positive, i.e. 0.064 with a $p$ value of $0.002(p<0.05)$ which is significant to the $5 \%$ significance level. The existence of positive relationship support the hypothesis on the basis of literature emphasizes that companies having larger size of the board have more cash holdings and when the board size is larger the monitoring process would enhanced because the decision making process is rigidized. The results are consistent with the conclusions of Kusnadi [27] and Gill and Shah [15].

Similarly, findings reveled that an insignificant relationship between board independence and corporate cash holdings exist. The regression coefficient value is positive, i.e. 0.086 with a $\mathrm{p}$ value of $0.128(\mathrm{P}>0.05)$ which is nonsignificant to the $5 \%$ level of significance hence, neglect the hypothesis on the basis of literature emphasizes that board independence have significant impact on cash holdings. This insignificant relationship means that board independence did not determine the cash holdings in the manufacturing sectors in Pakistan. The results are consistent with the conclusions of Wai and Zhu [49].

Results showed that a control variable like firm size has a positive and significant relationship with cash holdings because the $\mathrm{P}$-value is $0.023<0.05$. The regression coefficient value is 0.043 which shows that there exist a direct relationship between cash holdings and firm size. The presence of positive relationship emphasizes that corporations with larger size are kept to hold more cash because larger firms exhibit larger number of shareholders that tend them to the discretion of managerial. Alternatively, large amount of cash are detained by large firms with the intentions of preventing a takeover [14]. The results are reliable with the findings of Afza and Adnan [1]. 
Leverage has a highly significant and inverse relationship with cash holdings with $\mathrm{P}$-value equals to 0.000 , having a regression coefficient value of -0.202 which indicates that there exists an inverse connection between Leverage and cash holdings. The presence of negative relationship support the hypothesis on the basis of literature emphasizes that firm cash holdings decreases with the increase in debt ratio [39].The inverse relationship means that with the reduces in leverage in a structure of capital of a company there is an increase in cash holdings so firm can hold large amount of cash without subjecting them to monitor in the capital market. Moreover high leverage intensify underinvestment problem [37] because the increase in leverage might increase the earning capacity by investing the loan but there is also the possibility that if the loan is mismanaged and invest in unhealthy projects then in that case the firm might be face financial distress [8]. The results are reliable with the outcomes of [39], [14] and [1].

The findings also showed that there is a positive and significant relationship between cash flow variability and cash holdings at P-value $0.015<0.05$. The value of regression coefficient is 0.058 which means that there exist direct relationship between cash flow variability and cash holdings. Which emphasizes that cash holdings increases by the increase in variability of cash flow which will increase the investment opportunities [20] managers viewed the cash holdings as free cash flow and they used them for their own benefit at the cost of shareholders [20], [18]. The results are reliable with the results of Jensen [20] and Harford [18].

Growth opportunity is found to have a significant and positive effect on cash holdings. The $\mathrm{P}$ value is 0.021 $(\mathrm{P}<0.05)$ which is less than the $5 \%$ significance level and the regression coefficient value is 0.008 which means that a direct relationship exist between Growth opportunity and cash holdings. This means that companies with precious opportunities for investment and high cost of access to exterior capital have a tendency to have more cash to keep away from the higher cost of funding shortfalls. Therefore, companies with investment opportunities of high quality end to have more cash. The findings are reliable with the results of Opler et al. [41].

The findings also show that there is an insignificant and negative relationship between dividend and cash holdings. The $\mathrm{P}$-value is 0.834> 0.05. The value of regression coefficient is -0.004 , means that the dividend payout does not determine the corporate cash holdings in the manufacturing firms in Pakistan. The findings are reliable with the results of Khan, Bibi and Tanveer [24].

The results also showed that a positive and significant relationship exist between capital expenditures and cash holdings. The $\mathrm{P}$ value is $0.007<0.05$. The value of regression coefficient is 0.221 which means that a direct relationship exists between capital expenditures and cash holdings. This indicates that companies having surplus cash can have higher capital expenditures and, hence, such firms spend more on acquisitions. The positive relationship between cash holdings and capital expenditures also emphasizes that corporations having high capital expenditures can hold large amount of cash because capital expenditures can be used as a substitute for the cost of financial difficulties or to finance desired investment decision The findings are reliable with the findings of Nguyen [39] and Bates, Kahle and Stulz [6].

The findings also showed that model on the whole is highly significant because the $\mathrm{F}$ test value is 12.14 having a $\mathrm{P}$-value of 0.000 , lower than the $5 \%$ significance level. The $\mathrm{R}^{2}$ value is $62.67 \%$ which means that $62.67 \%$ of variations in cash holdings is due to the FPI inflows and corporate governance, that is, ownership concentration, board size, board independence and other control variables, that is, firm size, leverage, cash flow variability, growth opportunity dividend and capital expenditures while the remaining $37.33 \%$ of variations in cash holdings is because of a number of other unidentified factors which are not considered in the model. (For detail, see table 6). On the basis of results the hypotheses of the stated variables were accepted.

TABLE 6: IMPACT OF FDI AND CORPORATE GOVERNANCE ON CORPORATE CASH HOLDINGS

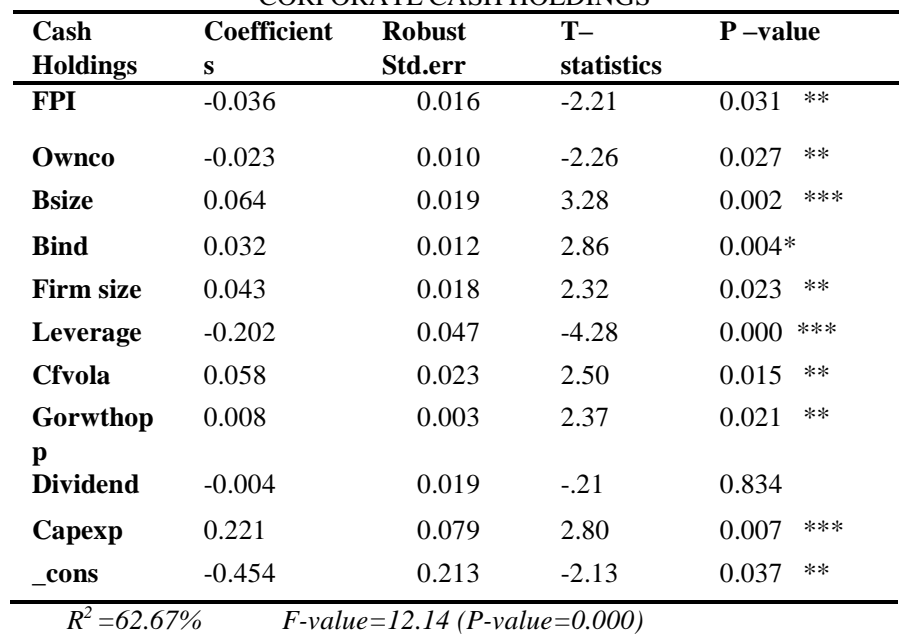

\section{CONCLUSION}

The aim of the current study is to examine the impact of foreign portfolio inflow and corporate governance on the corporate cash holdings in 67 firms for the period of 20132018 in the context of Pakistan. For data analysis step wise regression was used in which it is found that fixed effect model is most suitable. By analyzing the impact of FPI inflow on corporate cash holdings it was found that the connection between FPI and cash holdings was significant and negative. This inverse connection specify that the corporations tend to hold less cash holdings as the FPI inflow increases, hence, the corporate manager seemed the FPI inflows as a cash substitute. Evidently, a corporation with higher level of protection of investors have a tendency to exhibit low extent of risk and as a result foreign investors are willingly provide more funds for the purpose of investment. In terms of corporate governance, ownership concentration has a significant and negative impact, board size positive significant and board independence has negative insignificant impact on cash holdings. Hence it is concluded that within an effective practice of corporate governance the rights of investors are well protected and managers can perform in the best interest of investors by investing cash in healthy projects and the agency conflict is minimized. 


\section{SUGGESTIONS}

The following recommendations are made on the conclusion's basis they are:

1. In order to get advantage from foreign portfolio investment the firms should attempt to get better property rights and shareholder protection so that confidence reaches at a rank which is sufficient for investors to stay when macroeconomic changes take place.

2. In the end, procedures that will decrease volatility although still allow for the advantages of foreign portfolio investment may be put into place to initiate a valuable investment cycle that will enhance progress in foreign investment and domestic financial development in the long run.

3. For global source of financing the corporate manager must take financial decision which influences the flow of FPI.

4. The firm financial manager must invest cash in healthy projects to minimize agency problems.

5. The firms must adopt effective practices of corporate governance so as to protect rights of the shareholders and to attract and retain foreign investment.

\section{LIMITATIONS AND FUTURE DIRECTION}

The current study was restricted to manufacturing sectors namely Automobile, assembler Parts and electrical goods, Chemicals, cement sector, Engineering, Electricity (power) sector, Pharmaceuticals, glass and ceramics, Food producer (personal care products and sugar), Industrial metals and Mining, oil and gas sector and Personal goods sector listed on the Pakistan stock exchange. In future the researchers can select the remaining manufacturing and non-manufacturing sectors for investigating the problem. Current time period can also be taken because this has done from the period of 2013-2018. This study considered two variables such as foreign portfolio investment and corporate governance (ownership structure and board structure) to check the impact on cash holdings likewise, the other researchers can consider other sub variables of corporate governance such as Managerial Ownership, CEO duality, CEO ownership etc. for further study. Moreover, cross country analysis among the developing countries and the developed countries can also be a considerable dimension for future research.

\section{REFERENCES}

[1] Afza and S.M. Adnan. (2007). Determinants of corporate cash holdings: A case study of Pakistan. Proceedings of Singapore Economic Review Conference (SERC) 2007, August 01-04, Organized by Singapore Economics Review and the University of Manchester Singapore 164-165.

[2] Almudehki, N., \& Zeitun, R. (2012). Ownership structure and corporate performance: Evidence from Qatar.

[3] De Andres, P., Azofra, V., \& Lopez, F. (2005). Corporate boards in OECD countries: Size, composition, functioning and effectiveness. Corporate Governance: An International Review, 13(2), 197-210

[4] Barbosa, N., \& Louri, H. (2002). On the determinants of multinationals' ownership preferences: evidence from Greece and Portugal. International Journal of Industrial Organization, 20(4), 493-515.

[5] Barclay, M. J and C.W. Jr. Smith. (1995). The maturity structure of corporate debt. The Journal of Finance, 50, pp. 609- 631.

[6] Bates, T., Kahle, K. and Stulz R. (2009). "Why Do U.S. Firms Hold
So Much More Cash than They Used To?". The Journal of Finance. Vol LXIV, No. 5, October.

[7] Basheer, M. F. (2014). Impact of Corporate Governance on Corporate Cash Holdings: An empirical study of firms in manufacturing industry of Pakistan. International Journal of Innovation and Applied Studies, 7(4), 1371

[8] Baskin, J. (1987). Corporate Liquidity in Games of Monopoly Power. Rev. Econ. Stat., 69(2): 312-319.

[9] Castiglionesi, S. R. D. F. (2012). "What Determines Cash Holding of A Firm? Evidence from Euro-Zone Listed Firms". [Online] Retrieved from: http://arno.uvt.nl/show.cgi?fid=127364.

[10] Chaudhry. I. S, Fatima. F and Arzoo. M. (2014).Factors affecting portfolio investment in Pakistan: evidence from time series analysis. Pakistan Economic and Social Review Volume 52, No. 2, pp. 141158.

[11] Cossin. D and T. Hricko. (2004). The Benefits of Holding Cash: A Real Options Approach. Managerial Finance, 30(5), 29-43.

[12] Drobetz. W and M.C. Grüninger. (2007). Corporate cash holdings: Evidence from Switzerland. Financial markets Portfolio, 21, 293324.

[13] Eisenberg, T., Sundgren, S., \& Wells, M. T. (1998). Larger board size and decreasing firm value in small firms1. Journal of financial economics, 48(1), 35-54.

[14] Ferreira. M. A and A.S. Vilela. (2004). Why do firms hold cash? Evidence from EMU countries. European Financial Management, 10(2): 295-319.

[15] Gill, A and C. Shah. (2012). Determinants of corporate cash holdings: evidence from Canada. International Journal of Economics and Finance, 4(1), p70.

[16] Guney, Y., N. Ozkan and A. Ozkan. (2007). International evidence on the linear impact of Leverage on Corporate cash holdings. Journal of Multinational Financial Management, 17:45-60.

[17] Harford., A.M. Sattar and F. W. Maxwell. (2008). Corporate governance and firm cash holdings in the US Journal of Financial Economics.87:535-555

[18] Harford. J. (1999). Corporate Cash Reserves and Acquisition. Journal of Finance, 54:1969-1997.

[19] Islam, S. (2012). "Manufacturing Firms' Cash Holding Determinants: Evidence from Bangladesh". International Journal of Business and Management, 7(6), p. 172.

[20] Jensen, M. C. (1986). Agency cost of free cash flow, corporate finance, and takeovers. In American Economic Review, 76: 3-43.

[21] Jensen, M. C and W. H. Meckling. (1976). Theory of the firm: Managerial behavior, agency costs and ownership structure. Journal of Financial Economics 3: 305-360.

[22] Jensen, M. C. (1993). The Modern Industrial Revolution, Exit, and the Failure of Internal Control Systems. Journal of Finance. 48; 831880.

[23] Keynes. J.M. (1936). The General Theory of Employment. In: Interest and Money. Harcourt Brace. London.

[24] Khan, A., Bibi, M and Tanveer, S. (2016). The impact of corporate governance on cash holdings: a comparative study of the manufacturing and service industry. Financial Studies, 20(3), 40.

[25] Kiyoung, C and N. Abbas. (2006). Corporate cash holdings, Foreign direct investment and Corporate governance. Global finance journal, 16: 302-316.

[26] Kengatharan, L. (2017). Impact of Corporate Governance Practices on Firm's Cash Holdings in an Emerging Market: A Panel Data Analysis. International Journal of Accounting and Financial Reporting, 7(2), 210-224.

[27] Kusnadi, Y. (2004). Corporate governance mechanisms and corporate cash holdings.

[28] Kusnadi, Y., \& Wei, K. J. (2011). The determinants of corporate cash management policies: Evidence from around the world. Journal of Corporate Finance, 17(3), 725-740

[29] Kula, V. (2005). The impact of the roles, structure and process of boards on firm performance: evidence from Turkey. Corporate Governance: An International Review, 13(2), 265-276

[30] La Porta, R., F. Lopez-de-Silanes., A. Shleifer and R. W. Vishny. (2000). Agency problems and dividend policies around the world Journal of Finance 55:1-33.

[31] Lipsey, R. (1999). The location and characteristics of U.S affiliates in Asia. NBER Working Paper No. 6876.

[32] Lipton, M and J. W. Lorsch. (1992). A modest proposal for improved corporate governance. The Business Lawyer, 48, 59-77.

[33] Markowitz. H. (1952). "Portfolio Selection". The Journal of 
Finance, Vol. 7, No. 1.pp. 77-91.

[34] Mak, Y. T and Y. Li. (2001). Determinants of corporate ownership and board structure: evidence from Singapore. Journal of Corporate Finance, 7(3), 235-256.

[35] Masood. A and A. Shah. (2014). Corporate Governance and Cash Holdings in Listed Non-Financial Firms in Pakistan. Business Review, Vol.9 No.2, pp 48-72

[36] Megginson, W. L., \& Wei, Z. (2010). Determinants and value of cash holdings: Evidence from China's privatized firms. In 23rd Australasian Finance and Banking Conference.

[37] Myers, S.C. (1977). Determinants of Corporate Borrowing. Journal of Finance. Econ., 5(2): 147-175.

[38] Myers, S.C and R.G. Rajan. (1998). The Paradox of Liquidity. The Quarterly Journal Of Economics 113:733-771.

[39] Nguyen, P. (2005). How sensitive are Japanese firms to earnings risk? Evidence from cash holdings. 1-41.

[40] Opler, T., L. Pinkowitz., R. Stulz and R. Williamson. (1999). The Determinants and Implications of Corporate Cash Holdings. Journal of Financial Economics52:3-46.

[41] Ozkan, A and N. Ozkan. (2004). Corporate Cash Holdings: An Empirical Investigation of UK Companies. Journal of Banking and Finance, 28: 2103-2134.

[42] Pal, P. (2006). Foreign Portfolio Investment. Stock Market and Economic Development: A Case.

[43] Papaioannou, J. George., Strock. Elizabeth, Travlos and G. Nickolas (1992). Ownership structure and corporate liquidity policy. In: Managerial and decision economics 13, 315-322.

[44] Pouraghajan, A. A., Pourali, M.R., and Akbari, L. (2015) "Relationship between Ownership Structure and Corporate Cash Holdings in Iran". Applied mathematics in Engineering, Management and Technology, 3(1), pp. 771-778.

[45] Raithatha, M \& V. Bapat. (2012). Corporate Governance Compliance Practices of Indian Companies. Research Journal of Finance and Accounting, 3(8), 19-26.

[46] Shah, A. (2012). The corporate cash holdings: Determinants and implications. African Journal of Business Management, 5(34), 12939-12950.

[47] Eisenberg, T., Sundgren, S., \& Wells, M. T. (1998). Larger board size and decreasing firm value in small firms1. Journal of financial economics, 48(1), 35-54.

[48] Stulz, R. (1990). Managerial Discretion and Optimal Financing Policies. Journal of Financial Economics, Vol. 26, pp. 3-27.

[49] Wai, W. Y., \& Zhun, Y. (2013). The Effect of Corporate Governance on Cash Holdings: Evidence from Hong Kong Baptist University Hong Kong.

[50] Yermack, D. (1996). Higher market valuation companies with a small board of directors. Journal of Financial Economics 40, 185212.

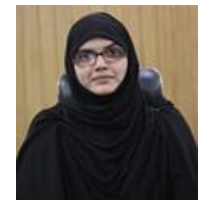

Hina Gul - Assistant Professor: Department of Management Sciences Abasyn University Peshawar Pakistan Email : hina.gul@abasyn.edu.pk.

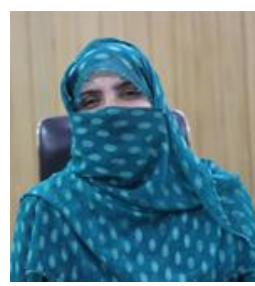

Sajida Gul - Assistant Professor: Department of Management Sciences Abasyn University Peshawar Pakistan. Email : sajida.gul@abasyn.edu.pk.

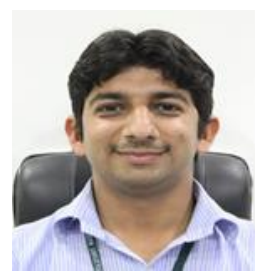

Shahid Rasheed - Assistant Professor: Department of Management Sciences Abasyn University Peshawar Pakistan. Email:shahid.rashid@abasyn.edu.pk. 